\section{"Sen polski": przypadek romantyków i nie tylko}

Michał Kuziak

TEKSTY DRUGIE 2016, NR 5, S. 97-121
Artykuł powstał w ramach grantu NPRH Romantyzm środkowoeuropejski w perspektywie postkolonialnej, $12 \mathrm{H} 12005881$.
Specjalny rodzaj snów niespokojnych.

Wyśnionych nagle izgodnie z programem. Weśnie.

Czerwień i biel...
Michał Kuziak dr hab., profesor UW (Zakład Komparatystyki ILP). Autor książek poświęconych Mickiewiczowi (m.in. Inny Mickiewicz, 2013) i Słowackiemu (Fragmenty o Stowackim, 2001), retoryce (Jak mówić, rozmawiać, przemawiać? kolejne wydania od 2005), a także ponad stu artykułów dotyczących literatury romantycznej i współczesnej oraz teorii literatury i komparatystyki literackiej. Redaktor wielu książek. W kadencji 2015-2018 członek Komitetu Nauk o Literaturze PAN. Kontakt: michakuziak@wp.pl 
twórczości poety (np. Król-Duch); w końcu: Krasiński, rozgrywający m.in. we śnie dramat swojej słabości i mocy, o czym zaświadcza korespondencja twórcy, wprowadzający do tekstów oniryczną poetykę, przedstawiający zarówno sny oddające stan katastrofy śniącego podmiotu, jak i prorocze, wizjonerskie, utrzymane w tonacji apokaliptycznej, związanej z przyszłością Polski i Europy $^{4}$. Dość przywołać tu jako przykład Nie-boska komedię . $^{5}$.

Romantycy nie tylko śnili i zapisywali swoje sny, nie tylko uczynili ze snu materię literatury, ale i teoretyzowali na ten temat, licząc na rozwiązanie w ten sposób wielu tajemnic uniwersum, a także na jego przekształcenie; przyjmując ponadto, że sen może być niebezpieczny, gdyż szczególnie intensywnie rozgrywa się w nim walka dobra ze złem; co ciekawe, wykorzystywali oni także metaforę snu jako bezczynności. Wypada ponadto pamiętać, że to z romantyzmu, m.in. w związku z rozwijającym się magnetyzmem, jego odłamem związanym z somnambulizmem i eksperymentami ze snem, swój rodowód wywodzi psychoanaliza ${ }^{6}$.

Swoista archeologia romantycznego snu, zarówno wizjonerskiego, jak i tego, który można określić jako psychologiczny - to zresztą często rozróżnienie służące jedynie intencji porządkowania, naruszające skomplikowanie i wieloznaczność snu - została znakomicie zrekonstruowana m.in. w książce Alberta Béguina, zajmującego się romantyzmem niemieckim i francuskim. W podobnym duchu pisano o polskiej literaturze romantycznej. Wspomnę tu choćby artykuł Aliny Witkowskiej Onirologia i oniromania, zamieszczony w monograficznym, poświęconym snom i literaturze, wydaniu „Tekstów” z 1973 roku . Ujęcie takie pozwoliło ukazać, tak to ujmę, metafizykę i epistemologię snu romantycznego, a także antropologię śniącego romantyka, eksplorującego pokłady immanencji (czy też przez nią osaczanego), a zwłaszcza

1984. W związku z Lambrem zob. J. Tomkowski Narkotyczna wizja w poemacie "Lambro"Słowackiego, w: Style zachowań romantycznych. Propozycje i dyskusje, red. M. Janion, M. Zielińska, PIW, Warszawa 1986; Godziną myśli - S. Treugutt Sny z premedytacją, "Teksty” 1973 nr 2.

4 Zob. A. Bagłajewski W poszukiwaniu kształtu wizji, w: Zygmunt Krasiński. Pytania o twórczość, red. B. Kuczera-Chachulska, M. Prussak, E. Szczeglacka, Wydawnictwo UKSW, Warszawa 2005.

5 Zob. M. Piasecka Mistrzowie snu. Mickiewicz-Słowacki-Krasiński, s. 204 i n.

6 Zob. na ten temat L. Chertok, R. De Saussure Rewolucja psychoterapeutyczna. Od Mesmera do Freuda, przeł. A. Kowaliszyn, PWN, Warszawa 1988.

7 Zob. A. Béguin Dusza romantyczna i marzenie senne. Esej o romantyzmie niemieckim i poezji francuskiej, przeł. T. Stróżyński, słowo/obraz terytoria, Gdańsk 2011.

8 Zob. A. Witkowska Onirologia i oniromania, "Teksty” 1973 nr 2. 
- wychylającego się ku transcendencji. Sen romantyczny okazał się wielką przygodą inicjacyjną, poszerzającą i pogłębiającą ludzkie istnienie.

Ujęcie takie może prowadzić do zuniwersalizowania snu. W efekcie polski romantyk śni podobnie jak bohaterowie Novalisa i Nervala - to najczęstsze dotychczasowe kierunki porównań komparatystycznych - czy Blake'a; w podobny sposób wygląda jego senne życie wewnętrzne, praca pamięci i marzenia. Tak interpretowane sny ujawniają rezonans uniwersalnych archetypów (różnicuje je ewentualnie kontekst historyczny), poddanie władzy wizjonerskiej wyobraźni epoki, z jej skłonnością do mitów i symboli bądź władzy ekonomii wskazywanych przez szkoły psychoanalityczne, częściej zresztą Junga niż Freuda czy Lacana?.

Taka uniwersalna lektura twórczości „mistrzów snu” widoczna jest również we wspomnianej książce Piaseckiej, która dostrzega polską tematykę snów romantyków (zwłaszcza u Krasińskiego), ale nie wyciąga z tego konsekwencji, które mogłyby skutkować wprowadzeniem formuły „snu polskiego” i związaną z tym rekonstrukcją pola interpretacyjnego, wiodącą do pytania o oniryczny wymiar polskiej tożsamości romantycznej. Być może zresztą taka uniwersalizująca lektura polskiego romantyzmu stanowiła w latach 8o. i 9o., kiedy ze szczególną intensywnością zajmowano się jego wymiarem onirycznym, swego rodzaju odtrutkę na dominującą w badaniach nad tą epoką problematykę narodową, część dokonującego się w nich zwrotu egzystencjalistycznego. Być może też, pojawiającą się w snach romantycznych, problematykę polską uznawano po prostu za coś oczywistego ${ }^{10}$.

Zagadnienie „snu polskiego" przedstawia w swojej ostatniej książce Wojciech Owczarski. O sensowności podjęcia tej kwestii w odniesieniu do literatury polskiej przekonuje choćby istnienie, pominiętej zresztą przez autora, Pałuby Irzykowskiego, po odpowiednie przykłady można by sięgać także do literatury staropolskiej"1". Owczarski pyta o to, co śni się Polakom; wychodzi przy tym również poza, będące głównym materiałem książki, literaturę i teatr,

9 Sam Béguin kwestionował przy tym prawomocność ich roszczeń do badania romantyzmu i traktował psychoanalizę nie tyle jako jego hermeneutykę, ile raczej konfrontował jej ustalenia z literaturą romantyczną. Unikał też redukcjonizmu, rozpatrując twórców i ich dzieła w indywidualnych kontekstach, zwracając się wprawdzie szczególnie ku filozofii i teologii, ale nie omijając także poetyki. W takim uniwersalnym kierunku szły także rozważania autorów monograficznego numeru 2 "Tekstów" z 1973 roku, poświęconego snowi i literaturze. 
zajmując się snami osób starszych w domach opieki. Badacz w centrum swojego zainteresowania umieszcza sprawę kształtowania się podmiotowości, tego, jak powstaje ona we śnie. Znamienna jest przy tym niechęć Owczarskiego do snów traumatycznych, związanych z historią i polskimi tematami narodowymi, o których jakoby wiemy już wszystko². O tym, że nie da się ich pominąć, przekonuje jednak rozdział książki poświęcony Weselu Wyspiańskiego.

Rozumiem tę niechęć. Nie mam natomiast przekonania, że wspomniane sny powinniśmy zamknąć w archiwum dawnych opracowań. Nie twierdzę przy tym, że to jedyne „sny polskie”. Chcę natomiast zwrócić uwagę na kilka spraw, które, jak się zdaje, dotąd nam umykały: 1) na splot snu i mesjanizmu, wprowadzający w obręb konstruowanej ideologii, powszechnie traktowanej jako oczywista, piętno związanej z oniryczną wyobraźnią niejasności oraz w efekcie: 2) na wagę doświadczenia onirycznego dla kształtowania polskiej nowoczesnej tożsamości - traktuję bowiem mesjanizm romantyczny jako zjawisko nowoczesne, powstające przeciw nowoczesności, ale na jej gruncie. Trzecia kwestia to oczywiście wspomniane już senne doświadczanie katastrofy narodu, jej zapowiedzi i konsekwencji. Osobna sprawa to trwałość romantycznych "snów polskich”, śnionych w tekstach XIX i XX wieku, wpisany w nie (wśniony) naznaczony traumą głos z krypty, który powraca także współcześnie, wzmacniany kolejnymi wydarzeniami historycznymi ${ }^{13}$.

Zajmować będzie mnie to, jak podmiot, śniąc, konstytuuje się wobec przeżycia historycznej katastrofy bądź jej pochodnych, jak istnieje po doświadczeniu traumy, która wiedzie do rozpadu pola symbolicznego organizującego świat. Wykorzenia z niego, zmuszając bądź do trwania w tym stanie, bądź do poszukiwania nowych symboli i narracji. Przywołam tu utwory

12 Problematyką taką, posługując się pojęciem fantazmatu (nie odnosząc się jednak do tematyki onirycznej), zajmuje się M. Janion w książce Projekt krytyki fantazmatycznej. Szkice o egzystencjach ludzi i duchów, PEN, Warszawa 1991.

13 Ryszard Nycz, w kontekście projektu studiów postzależnościowych, pisze o "niemilknącym pogłosie w naszych głowach" (Wprowadzenie. "Nie leczony, chroniczny pogłos”..., w: Kultura po przejściach, osoby z przeszłościq̨. Polski dyskurs postzależnościowy - konteksty i perspektywy badawcze, red. R. Nycz, Universitas, Kraków 2011, s. 11). Zob. także artykuł M. Zaleskiego Czy polski dyskurs postzależnościowy może wybić się na niezależność? Ponadto - rozważania D. LaCapry o traumie i posttraumie, związkach zdarzeń urazowych z pamięcią i wyobraźnią w tomie Historia w okresie przejściowym. Doświadczenie, tożsamość, teoria krytyczna, przeł. K. Bojarska, Universitas, Kraków 2009 (tu także kategoria traumy historycznej). W perspektywie badań literaturoznawczych problem ten stawia G.H. Hartman Wiedza traumatyczna i badania literackie, przeł. J. Burzyński, w: Antologia studiów nad traumg, red. T. Łysak, Universitas, Kraków 2015. 
wspomnianych: Mickiewicza, Słowackiego i Krasińskiego - jako fundujące pole symboliczne „snu polskiego”. Utwory znane, ale, jak sądzę, tym bardziej warte kolejnej, umieszczającej je w nowym kontekście, lektury.

Wstępnie można przyjąć, że sen okazał się dla wskazanych autorów celnym, gdyż wieloznacznym - wystarczy przypomnieć o zróżnicowaniu związanej z nim metaforyki - zjawiskiem, pozwalającym zwrócić uwagę na niejasność i skomplikowanie sytuacji, w jakiej znalazł się polski podmiot przeżywający historię w drugiej połowie XVIII i pierwszej XIX wieku. Rama snu pozwala ponadto w specyficzny sposób doświadczać zagrożenia związanego z zakwestionowaniem autonomii państwa i narodu, podważającego odczucie stabilności świata, który otacza śniącego. Sen staje się w związku z tym wymiarem, w którym przeżywa on swoją słabość, ale i - tak jest w przypadku romantycznego "snu polskiego" - poszukuje mocy.

We śnie, jak powiada Freud, pracują mechanizmy kondensacji, przemieszczenia i symbolizacji, a także wtórnego opracowania, przekształcające i zniekształcające śnioną treść, nadające jej specyficzny obrazowy i fabularny charakter ${ }^{14}$. Pozwalają one na przeżycie tego, czego nie chce bądź nie może przeżyć podmiot na jawie. Pozwalają również na realizację pragnień niemożliwych czy trudnych do zrealizowania w rzeczywistości. Spotyka się we śnie praca pamięci z pracą marzenia. Można mówić o swoistej aporetyczności doświadczenia snu, w którym jednocześnie ujawnia się pragnienie konfrontacji z realnością, która jest nie do zniesienia, i niechęć do takiej konfrontacji; bliskość uwewnętrznionego doświadczenia i zdystansowanie związane z niejasnym statustem jego ontologii; to, co racjonalne i to, co irracjonalne, eksponujące ograniczenia poznania na jawie i wypowiadającego je „dziennego” języka, naruszające logiczny charakter przekazu (bez wątpienia, ta kwestia wywoływała szczególne zainteresowanie snem u romantyków). Sen okazuje się w efekcie skomplikowanym palimpsestem znaczeniowym, szyfrem skrywającym i odsłaniającym prawdę śniącego ${ }^{15}$.

14 Zob. na ten temat Z. Freud Objaśnianie marzeń sennych (Dzieła, t. 1), przeł. R. Reszke, KR, Warszawa 1994; a także H. Segal Królewska droga, w: Marzenie senne, wyobraźnia i sztuka, przeł. P. Dybel, Universitas, Kraków 2003. Jak zauważa badaczka, Freuda nie zajmują kulturowe symbole w pracy marzenia sennego, gdyż traktuje je jako uniwersalne, wywodzące się z pradawnych czasów (s. 19). Przedmiotem mojego zainteresowania są pojawiające sie w snach literackich symbole, organizujące doświadczanie historii. 


\section{Dwa XX-wieczne "senniki polskie"}

Zacznę od końca, choć przecież historia „snu polskiego" jeszcze, jak się zdaje, nie jest skończona. Sny takie, o czym przekonuje choćby Morfina Szczepana Twardocha, ciągle nawiedzają literaturę polską i jej bohaterów ${ }^{16}$. Bohater-narrator Sennika wspótczesnego Tadeusza Konwickiego powiada ${ }^{17}$ :

I wtedy raptem pomyślałem, że oto za chwilę obudzę się, wydźwignę z dusznego snu, co na każdego przychodzi którejś nocy, snu pełnego majaków i widziadeł, ułomków zdarzeń przeżytych i zmarnowanych, wyobrażonych i nie spełnionych, snu skrwawionego pamięcią, rozpalonego gorączką przeczucia, że z tej wrzącej toni nocy wypełzną resztki sił na brzeg jawy i wstaną do zwyczajnego, powszedniego dnia z jego wszystkimi troskami, z jego potocznym trudem, z jego tak dobrze znaną, bliską znojnością. ${ }^{18}$

Fragment ten jest ostatnim zdaniem powieści. Przebija zeń pragnienie wybudzenia i rozpoczęcia zwykłego życia, zrywającego z przekleństwem

16 Pisząc o „śnie polskim”, wypadałoby zacząć od tekstów z końca XVIII wieku (wspomnę choćby o wierszu Woronicza Zjawienie Emilki, będącym elegijnym rozpamiętywaniem klęski Polski i śmierci jej bohaterów, czy o Śnie Józefa Morelowskiego, w którym rozważana jest kwestia winy (jej braku) Polaków za upadek państwa, bądź o Wierszu do Legiów polskich Godebskiego, w którym we śnie dokonuje się przemiana polskiego sarmaty gospodarza w żołnierza, a także zostaje ujawniona specyfika życia zniewolonego kraju). "Sny polskie” pojawiają się także w utworach drugiej połowy XIX wieku. Nadmienię o pamięci powstania i emigracyjnej pamięci kraju (Latarnik Sienkiewicza), historii walk o niepodległość (Popioły Żeromskiego), swoistym spektaklu polskości (Wesele Wyspiańskiego) czy o Płomieniach Brzozowskiego, w których sen jest zarówno metaforą utopijnego projektu społecznego, jak i okazuje się "snem polskim" w takim znaczeniu, o jakim piszę w artykule, mając na uwadze katastrofę upadku państwa i jej konsekwencje. W literaturze XIX stulecia uwagę zwraca ponadto doświadczenie nowoczesności (również ważne polskie doświadczenie zależnościowe), które także może być przeżywane w kontekście snu. Myślę o bohaterze Lalki Prusa - Wokulskim, który wędruje po Paryżu w atmosferze onirycznej maligny. Wiek XX dodaje do tego zestawu sny wojenne: wspomnę choćby Widma Gajcego, Dwa teatry Szaniawskiego czy Czarny potok Buczkowskiego, Sennik polsko-żydowski Mariana Marzyńskiego, a także, by tak to ująć, po-wojenne, widoczne w Kartotece Różewicza czy w Utworze o matce i ojczyźnie Bożeny Keff. To oczywiście jedynie cząstkowa enumeracja biblioteki "snu polskiego".

Zob. na ten temat: Z. Marcinów „Zbudziłem się". Uwagi o konwencji onirycznej w powieściach Tadeusza Konwickiego, w: Oniryczne tematy i konwencje w literaturze polskiejXX wieku, red. I. Glatzel, J. Smulski, A. Sobolewska, Wydawnictwo UMK, Toruń 1999. 
traumatycznej pamięci nawiedzającej śniącego, mieszającej się z codziennymi wspomnieniami, pracą wyobraźni i przeczuciami przyszłości. Utwór rozpoczyna się zdaniem: „Nie otwierałem oczu i nie wiedziałem, jak rozbudzony z przedwieczornego snu, gdzie jestem i kim jestem. W ustach piekł jadowity smak żółci, po skroniach przebiegały łaskotliwe stonogi pulsu. Leżałem w ciężkim worku z bólu i potu"19. Śniący doświadcza dezintegracji siebie i otaczającego świata, zatraca poczucie rzeczywistości. Przeżycie to ma przy tym charakter somatyczny, wyraźnie wskazujący na syndrom chorobowy, widoczny także w cytowanym zdaniu wieńczącym Sennik wspótczesny.

Między ramami początku i końca powieści rozgrywa się spektakl maligny, nawiedzających sen bohatera-narratora koszmarów, przerywany wybudzeniami na równie niejasnej i męczącej jawie; sny tego typu są zresztą udziałem nie tylko Pawła - głównego bohatera Sennika wspótczesnego. Paradoksalnie przy tym sny w utworze Konwickiego okazują się zarówno przestrzenią powrotu bolesnej pamięci, jak i ucieczki przed nią. Procesy poznawcze w istniejącym w onirycznej ramie świecie są zdominowane przez postrzeganie, zresztą niejasnych, często groźnych, wywołujących lęk podobieństw i reminiscencji. Zdają się one władać podmiotem, zamykając w przeszłości, łudząc iluzją prawdy, uniemożliwiając mu pełne istnienie w jego współczesności, podporządkowując to, co indywidualne - narodowemu.

Pamięć o przeszłości odznacza się w Senniku współczesnym fragmentarycznością i niejasnością, aluzyjnością; nie wszystko można powiedzieć w realiach PRL-u, a także nie wszystko można pamiętać w jasny sposób - dowiadujemy się, że bohater doświadczył zbyt wiele, że tkwi w nim wspomnienie traumy ${ }^{20}$. Wprost odsyła głównie do wydarzeń II wojny światowej. Jest mowa o działalności partyzantki, tajemniczej, ciągle kładącej się cieniem na współczesności, o ofiarach Niemców (również ofiarach żydowskich), o przemianach społecznych, które, nie bez udziału wschodniego sąsiada, zmieniły dawny świat, także o oporze wobec nich. Bohaterowie powieści zdają się pozbawieni świadomości, która pozwoliłaby im w pełni zrozumieć wydarzenia, w których uczestniczyli. To jakby inspiracja dla Prześnionej rewolucji Andrzeja Ledera.

Pojawia się w powieści także pamięć obejmująca szerszą sekwencję wydarzeń traumatycznych, sięgająca ku I wojnie światowej, a nawet zawierająca

19

20

Tamże, s. 5 . Zob. B. Żynis Koniec świata raz jeszcze. Katastroficzne wątki w prozie Tadeusza Konwickiego, AP,
Słupsk 2003, s. 22 i n. 
ślady powstania 1863 roku. Pamięć w Senniku wspótczesnym ma również wymiar materialny: jest mowa o rzeczach należących do uczestników wydarzeń i ofiar, o mogiłach, bunkrach, pobojowiskach. Poszerza ją lektura - wzmiankowane są Popioły Żeromskiego. Szczególnie znaczenie ma przy tym pamięć, najczęściej wprowadzana aluzyjnie, związana ze wschodnim („kresowym”) rodowodem bohaterów. Towarzyszy jej budująca poczucie niestabilności świadomość utraty dawnego własnego świata oraz istnienia w nowym świecie ludzi wykorzenionych, o niejasnym pochodzeniu, usiłujących uciec przed swoim losem, bądź zapomnieć o przeszłości, bądź ją odzyskać.

Senny świat, który ukazuje Konwicki, sprawia wrażenie prowizorycznego, zrujnowanego i zdegradowanego. To rzeczywistość już po katastrofie, po wielu katastrofach... i zarazem jakby oczekująca na ostateczny koniec, który wiąże się także z inwazją nowoczesności - powstająca hydroelektrownia ma zniszczyć świat przesyconej pamięcią przeszłości doliny. Wspomniane jest np. pozbawione wyrazu urbanistycznego peryferyjne miasteczko, wielokrotnie niszczone, które nie mogło stać się organiczną całością, a w którym spotykało się niegdyś wiele kutur, tradycji, języków i religii. Podobnie zdegradowani są ludzie i ich życie w takim świecie, naznaczone poczuciem klęski²1.

Ze snów wymieszanych z fragmentami równie niepewnej jawy nie powstaje w powieści Konwickiego całościowa narracja o świecie czy bohaterze - ten, jak czytamy, napisał kilkadziesiąt różnych życiorysów. Pragnie on odkryć sens przeżywanych doświadczeń2 ${ }^{2}$. Pozostają mu wszakże pochodzące $\mathrm{z}$ różnych porząadków czasowych strzępy zdarzeń i wypowiedzi (niejednokrotnie sprzecznych). Sen zdaje się przygnębiającym stanem istnienia świata i podmiotu, nierealnym, ale dotkliwym, oddającym słabość człowieka i grozę historii.

To nie jedyny „sennik polski” pojawiający się w literaturze XX wieku. Proponuję sięgnąć tu jeszcze do Ślubu Witolda Gombrowicza. Wybór ten może zaskakiwać, gdyż zarówno autor, jak i komentatorzy dramatu starali się eksponować przede wszystkim jego uniwersalny, ogólnoludzki, charakter, mniej zajmując się kontekstem polskim. Badacze najczęściej przyjęli przy tym z pełną wiarą komentarze pisarza odsyłające w myśleniu o jego utworze do

Zob. S. Chwin Sny nad "wierną rzekq". Tadeusz Konwicki i romantyczne przeżycie losu, w: Romantyczna przestrzeń wyobraźni, Pomorze, Bydgoszcz 1988, s. 180 i n. 
dramaturgii Szekspira i Goethego ${ }^{23}$, przemilczające natomiast ostentacyjne nawiązania do III części Dziadów, Kordiana i Nie-boskiej komedii ${ }^{24}$. Jednocześnie wszakże dane przez Gombrowicza streszczenie dramatu wyraźnie lokalizuje jego akcję, wpisując ją zarówno w sen bohatera, jak i w realia polskie. Sen ten bowiem jest śniony „we Francji podczas ostatniej wojny”, pojawia się w nim „jego [Henryka - M.K.] dom w Polsce i rodzice"25.

Świat przedstawiony (śniony) dramatu nie tyle jest, ile „wydaje się" czymś innym, niż był czy powinien być. Tak okazuje się z domem (obecnie karczmą), rodzicami Henryka (karczmarzami) i jego narzeczoną (służącą). Rzeczy, podmiot, język zatracają swoją tożsamość, stają się niestabilne; jawa i sen zdają się przemieszane i nieodróżnialne. Powrót do dawnego świata okazuje się niemożliwy. Jak czytamy w przywołanym już streszczeniu Gombrowicza, Henryk „widzi się wobec świata fikcji, snu, kłamstwa, świata formy"26. I w tym przypadku, podobnie jak w powieści Konwickiego, poznanie umocowane jest w kategorii reminiscencji i niejasnego podobieństwa - rzeczywistość coś przypomina, jest trochę podobna bądź podobna i niepodobna, podobna do wszystkiego, a niepodobna do siebie; w efekcie okazuje się niepoznawalna bądź poznawalna w sposób niepewny.

Przemiana dawnego świata - znów wypada odnotować analogię z Sennikiem wspótczesnym - wiąże się $\mathrm{w}$ dramacie z jego degradacją; czytamy o: "przeinaczeniu”, „wykręceniu”, ,zrujnowaniu”, ,wypaczeniu”, ,zaszpuntowaniu”, ,zakneblowaniu”, „zamaskowaniu”. Utwór otwiera wizyjne, oniryczne przedstawienie ruin dawnego kościoła - rzeczywistości „przygnębiającej i beznadziejnej". To, co się dzieje w nowym, powojennym (? - stawiam znak zapytania, gdyż realia czasowe utworu nie są jasne, a także dlatego, że sen przynosi wizję kolejnej rozpoczynającej się wojny), wymiarze, zostaje określone mianem farsy. W perspektywie pamięci, w formule „dawniej”,

23 Zob. J. Błoński „Ślub” jako tragedia psychoanalityczna, w: Forma, śmiech i rzeczy ostateczne: Studia o Gombrowiczu, Universitas, Kraków 1994, s. 113 i n.; ponadto: M. Bukowska-Schielmann Lęk $i$ wina. Prezentacje snu w dramacie powojennym, w: Oniryczne tematy $i$ konwencje $w$ literaturze polskiejXX wieku,. W związku ze snem tendencja uniwersalizowania dramatu w badaniach wiąże się z poszukiwaniem w nim freudowskich mechanizmów cenzury i pragnienia.

Pisałem o tym szerzej w artykule "Ślub" w kościele międzytekstowym (o śladach romantyzmu w dramacie Witolda Gombrowicza), „Przegląd Artystyczno-Literacki” 1998 nr 11. W. Gombrowicz Ślub, w: Dramaty (Dzieła, t. 6), red. nauk. J. Błoński, Wydawnictwo Literackie, Kraków 1988, s. 95. 
funkcjonuje świat normalności, ostatnich zdarzeń, które w nim zaszły, zapewne przed wojną, i które odznaczają się wyrazistą tożsamością, są naznaczone sensem. Ujęcie przeszłości różni Ślub od powieści Konwickiego, w której nie pojawiła się taka przeszłość, a ta, która się pojawiła, okazała się podobnie niejasna, jak współczesność.

W miarę rozwoju akcji w Ślubie sytuacja staje się coraz mniej jasna, tak to ujmę: nie zmierza ani do rozpoznania, ani do oczyszczenia. Rośnie niepokój i lęk Henryka. Zdarzenia stają się coraz bardziej męczące. Bohater nie wie, kim jest, nie wie, gdzie się znajduje, nie wie, co robi, nie może odgadnąć sensu snu. W finale dramatu powiada: „Ja nic, nic nie wiem, nic nie rozumiem! / Kto z was twierdzi, że rozumie, ten kłamie!"27. Gombrowicz nie ukazuje wyzwalającej perspektywy wybudzenia się. Henryk wprawdzie jest przekonany, że może się obudzić - widać w utworze dynamikę zbliżania się do jawy i oddalania od niej; jak pisze Jan Błoński, „półżartem”, „Gombrowicz manipuluje głębokością snu"28 - ale zarazem sądzi, że wtedy otaczająca go rzeczywistość może zniknąć. A więc istnieje możliwość, że zniknie wszystko, również on sam. Nie ma więc w dramacie kartezjańskiego odbudowania pewności po doświadczeniu wątpienia.

Wypadki nieuchronnie prowadzą do katastrofy - projektu zarówno restytucji dawnych, jak i tworzenia nowych rytuałów. Międzyludzkie bezlitośnie zapanowuje nad ludźmi, którzy usiłowali poddać je swojej władzy, zagraża im. Podjęta przez Henryka próba ustanowienia siebie jako mocnego podmiotu - odbudowy rytualnego charakteru świata - kończy się tyranią i klęską bohatera. Po sprowokowanym samobójstwie Władzia, stanowiącym część planu przywracania ładu, z przerażeniem, ale i nadzieją Henryk stwierdza/ pyta, czy to sen.

Senny, niejasny i groźny stan świata Ślubu zostaje oddany przez język dramatu, przemieniający się w bełkot, naruszający logikę i pozwalający snuć najbardziej, zdawać by się mogło, szalone myśli, zastępujący relacje przyczyny i skutku relacjami metafory i najczęściej metonimii, poświadczający w ten sposób brak sensu organizującego rzeczywistość.

Sen z Sennika wspótczesnego i sen ze Ślubu zaczął być śniony w romantyzmie, choć można przywołać także jego wcześniejsze realizacje, pojawiające

Tamże, s. 222.

28 J. Błoński „Ślub” tragedia psychoanalityczna, s. 114. Jak akcentuje M. Głowiński, Ślub zawiera także refleksję na temat snu (Komentarze do „Ślubu”, w: Gombrowicz i krytycy, wyb. i oprac. Z. Łapiński, Wydawnictwo Literackie, Kraków 1984, s. 651). 
się w klasycystycznej literaturze porozbiorowej. Zresztą zarówno powieść Konwickiego, jak i dramat Gombrowicza odsyłają do niego w sposób mniej lub bardziej jawny ${ }^{29}$. Myślę np. o wspomnianej, związanej z powstaniem styczniowym, genealogii polskiego losu, która zostaje wskazana w Senniku wspótczesnym, jak również o dostrzeżonym przez Stefana Chwina przywoływaniu w nim wzorców romantycznych i ich degradacji; badacz porównuje bohatera-narratora powieści z Gustawem ${ }^{30}$. W przypadku Ślubu w grę wchodzą interteksty odsyłające m.in. do III części Dziadów, również do „sennych” scen dramatu Mickiewicza.

Oczywiście u Gombrowicza wypada także zauważyć pracę parafrazy, mającej na celu nie tylko (a może nie tyle?) degradację wzorców romantycznych, ale i ich, wspomnianą już, uniwersalizację, wydobycie z kontekstu narodowego. Punktem wyjścia w utworze, jak nadmieniłem, jest sytuacja w trakcie wojny. Pisarza zdaje się jednak bardziej interesować, tak to ujmę - ogólny kulturowy stan świata. Wspomniany kontekst pozostaje wszakże rozpoznawalny, rezonujący znaczeniami, naznaczając to, co uniwersalne, swoją partykularnością, wiążąc ów stan świata z polskim doświadczeniem permanentnej destabilizacji istnienia.

Sen dla obu pisarzy okazuje się wymiarem pozwalającym konceptualizować i metaforyzować przeżycie, które można określić mianem (post)zależnościowego ${ }^{31}$, a które w obu przypadkach współtworzy „dramat jaźni” bohaterów ${ }^{32}$. Sen pozwala ukazać stan świata po historycznej katastrofie, rozpad organizującego go pola symbolicznego oraz związaną z tym dezintergrację śniącego, również rozpad konstruowanych przez niego narracji, używanego języka, brak możliwości poznania świata i mocy sprawczej.

Wydaje się, że celnie istotę doświadczenia sennego, o którym piszą Konwicki i Gombrowicz, może oddać Freudowska kategoria Unheimliche. Zawiera ona bowiem w sobie myśl o splocie tego, co znane, z tym, co nieznane, o nagłej i niewytłumaczalnej przemianie tego pierwszego w drugie, przemianie

Zob. A. Fabianowski Konwicki, Odojewski i romantycy. Projekt interpretacji intertekstualnej, Universitas, Kraków 1999, s. 27 i n.

Zob. S. Chwin Sny nad „wierną rzekq". Tadeusz Konwicki i romantyczne przeżycie losu, s. 176.

Oprócz prac wskazanych w przypisie 14 zob. także: H. Gosk Wychodzenie z "cienia imperium”. Wątki postzależnościwe w literaturze polskiejXX iXXI wieku, Universitas, Kraków 2015 (zwłaszcza rozdział Impuls postzależnościowy).

32 Tego pojęcia używa ). Błoński w interpretacji Ślubu („Ślub” jako tragedia psychoanalityczma, S. 116). 
zagrażającej podmiotowi i wywołującej w nim uczucie lęku. Freud pisał, że przemiana ta polega na nieprzepracowaniu i wyparciu znanego elementu z pola świadomości, a następnie powrocie wypartego: „Niesamowite nie jest tak naprawdę niczym nowym czy obcym, lecz jest czymś od dawna znanym życiu psychicznemu, czymś, co wyobcowało się z niego za sprawą procesu wyparcia"33.

Kwestia ta wygląda nieco inaczej u Konwickiego, u którego historia prowadzi do katastrofy świata - inaczej u Gombrowicza, u którego katastrofa, której towarzyszą doświadczenia historycze, jest niejako odsłonięciem uniwersalnej prawdy o świecie, o wpisanym weń deficycie sensu. Zwróćmy ponadto uwagę, że przywołane wyżej sny nie otwierają żadnej perspektywy inicjacyjnej, która mogłaby dać śniącemu szansę na zrozumienie i przepracowanie - choćby jedynie na gruncie fantazji - własnego doświadczenia. Nie wskazują na możliwość zaistnienia pola symbolicznego, które mogłoby na nowo porządkować świat (w Ślubie próba stworzenia takiego pola kończy się klęską).

\section{"Czy ty z rana choć jeden sen twój przypominasz" ${ }^{3_{4}}$}

Mickiewicz konstruuje, wpisaną w światopogląd romantyzmu, metafizyczną i poznawczą koncepcję snu, widoczną wyraźnie w III części Dziadów, korespondującą z tłumaczonym wcześniej wierszem Byrona Sen ${ }^{35}$. Konrad - polemizując z mędrcami, powołując się na własne doświadczenie - powiada, że sen nie wiąże się z pracą pamięci, nie jest przypomnieniem, nie jest także efektem pracy wyobraźni. Jest natomiast światem drugim, innym wymiarem istnienia ([...] ten świat cichy, głuchy, tajemniczy, / Życie duszy [... $\left.]^{36}\right)$, o którym w III części Dziadów mówi się językiem odsyłającym do wyobrażeń

Z. Freud Niesamowite, w: Pisma psychologiczne, przeł. R. Reszke, t. 3, KR, Warszawa 1997, s. 243.

A. Mickiewicz Dziady, cz. III, w: Dzieła [Wydanie Jubileuszowe], red. J. Krzyżanowski, Czytelnik, Warszawa 1955, s. 132.

Na temat snu i snów w twórczości Mickiewicza zob. M. Piasecka Mistrzowie snu. Mickiewicz Słowacki - Krasiński, s. 18. Autorka widzi w słynnym wierszu Śniła się zima element zjawiska, które określam mianem "snu polskiego", odczytując procesję na brzegu Jordanu z wiersza jako pochód męczenników sprawy wolności (s. 55). Ponadto: A. Witkowska Onirologia i oniromania; J.-Ch. Gille-Maisani Adam Mickiewicz człowiek. Studium psychologiczne, przeł. A. Kuryś, K. Rytel, PIW, Warszawa 1987, s. 341 i n.; Mickiewicz. Sen i widzenie, red. Z. Majchrowski, W. Owczarski, słowo/obraz terytoria, Gdańsk 2000; H. Krukowska Noc romantyczna. Mickiewicz, Malczewski, Goszczyński. Interpretacje, słowo/obraz terytoria, Gdańsk 2011.

A. Mickiewicz Dziady, cz. III, s. 129. 
chrześcijańskich ${ }^{37}$. Polemika ta, trzeba podkreślić, ma na celu przecięcie potencjalnego związku snu z podmiotem, uniezależnienie snu od aktywności człowieka, od jego życia codziennego oraz zaakcentowanie transcendentnego wymiaru zjawiska.

Sny w III części Dziadów - te bowiem będą mnie tu interesować w związku z problemem „snu polskiego" u Mickiewicza, w tym przypadku zwłaszcza snu więźnia - zdają się wszakże mieć rozmaity charakter. Nie tylko wiążą się ze wspomnianym światem drugim, o którym pisano dotąd najwięcej - anioł zabiera duszę Gustawa/Konrada do nieba, podobnie dzieje się z duszą ks. Piotra po jego widzeniu, Ewa spotyka we śnie anioły. Ale i wynikają z życia podmiotu, zwłaszcza z jego pamięci, „okruchów dnia”, psychologii, być może także fizjologii. Znamienne przy tym, że im bardziej bohater jest oddalony od kreowanego przez poetę wzorca heroicznego, tym bardziej jego sny oddalają się od wymiaru metafizyki. Kierują się logiką indywidualnych pragnień i lęków.

Skrajnym przykładem takiej sytuacji jest Senator i jego sen; byty metafizyczne, które biorą w nim udział, dręczące bohatera diabły, co znaczące, pochodzą z piekła - to ono stanowi świat drugi śniącego... Sytuacja ta oddaje zarówno podłość bohatera, jak i specyfikę życia w państwie despotycznym, życia podwójego, bowiem Senator należy do porządku władzy, a zarazem jego los jest niepewny, zdany na kaprys imperatora. Senator ustanawia się i rozpoznaje w jego oczach, usiłując przekonać go o swoim oddaniu. Droga od uznania i wywyższenia po upadek okazuje się jednak niezwykle krótka, co zostaje oddane w dramatycznej fabule snu.

Powróćmy do Konrada. Dusza uwięzionego, ukazywanego jako dziecko, jest prowadzona $w$ trakcie snu do nieba ${ }^{38}$. Bohater jednak nie potrafi rozpoznać duchowego wymiaru tego doświadczenia. Traktuje je - jak stwierdza przewodnik Anioł Stróż - jakby to była zabawa w nocnym Wilnie. Sen bohatera w Prologu i Scenie więziennej ukazuje jego zagubienie w rzeczywistości, w której panuje niejasność; młodzi więźniowie są oskarżeni o antyrządowy spisek - poeta prezentuje ich wszakże jako niewinne i niewiele rozumiejące dzieci. Anioł Stróż mówi:

I dusza twa w niepokoju,

Ale z dumą się budziła,

Zob. M. Piasecka Mistrzowie snu. Mickiewicz - Słowacki-Krasiński, s. 29 in.

Zob. na ten temat W. Weintraub Poeta i prorok. Rzecz o profetyzmie Mickiewicza, PIW, Warszawa 1982 , s. 189 in. 
Jakby w niepamięci zdroju

Przez noc całą męty piła.

I pamiątki wyższych światów,

W głąb ciągnąłeś, jak kaskada,

Gdy w podziemną przepaść wpada,

Ciągnie liście drzew i kwiatów. ${ }^{39}$

Konrad znajduje się w więzieniu, które zarazem, jak stwierdza Anioł, stanowi próbę inicjacyjną, zapewne związaną z przyszłą misją bohatera. Usiłuje zrozumieć spotykające go wydarzenia, zarówno na jawie, jak i we śnie; rytm Prologu, wzmocniony fragmentarycznymi wypowiadziami Gustawa/Konrada, to naprzemienność budzenia się i zasypiania; jedno z takich wybudzeń skutkuje symboliczną zmianą imienia. Bohater pyta o tajemnicę przyszłości i los narodu. Dociekliwość poznawcza bohatera kończy się wszakże klęską w Małej i Wielkiej Improwizacji ${ }^{40}$. Ciagle nie rozpoznaje on swojego przeznaczenia, jakby pozostawał pogrążony we śnie, traktowanym jako stan zagubienia.

Sen, który w III części Dziadów jest wydarzeniem poznawczym, może być także stanem oddającym kłopot z poznaniem i w efekcie problem tożsamościowy śniącego, również utratę jego mocy sprawczej. We śnie przychodzą do niego przy tym zarówno dobre, jak i złe, kuszące duchy. W Prologu bohater poznaje tylko to, że zostanie uwolniony z więzienia i zesłany - nie może wszakże uświadomić sobie, skąd o tym wie - z czym łączy się obawa poety pozbawionego swoich słuchaczy/czytelników, skazanego na zamilknięcie, a więc na pewien rodzaj śmierci oraz poczucie upokorzenia.

Mickiewicz wyraźnie kontrastuje w dramacie drogę Konrada, naznaczoną błądzeniem, z drogą Ewy oraz ks. Piotra, którym dane zostaje wtajemniczające widzenie. W przypadku bohaterki dochodzi do niego we śnie, w przypadku bohatera - widzenie kończy się snem, w którym aniołowie zabierają duszę śpiącego do nieba. Owe widzenia mają hermetyczny, symboliczny charakter, są fragmentaryczne i pozbawione wyraźnych konkluzji ${ }^{41}$. Stanowią znak

39 A. Mickiewicz Dziady, cz. III, s. 129.

40 Jako sen interpretuje Wielką Improwizację, co jednak zdaje się wyborem hermeneutycznym mającym na celu, paradoksalnie, zracjonalizowanie tej sceny, M. Piasecka (Mistrzowie snu. Mickiewicz - Słowacki-Krasiński, s. 63 i n.).

41 To specyfika Mickiewiczowskiej apokalipsy, pisanej od lat 30. po lata 40. XIX wieku. Szerzej piszę na ten temat w tekście: Mickiewiczowska apokalipsa. Wokół IV kursu prelekcji paryskich, w: O prelekcjach paryskich Adama Mickiewicza, AP, Słupsk 2007. 
wejścia w świat metafizyki, choć także wyrastają z codzienności bohaterów, jednak innej od tej, która była udziałem Konrada czy zwłaszcza Senatora. Ewa i ks. Piotr modlą się oraz akcentują ograniczenie własnej podmiotowości, która okazała się niezbywalnym aspektem istnienia Konrada. Takie postępowanie stanowi warunek fortunnego wtajemniczenia.

Wspomniane widzenia - w przypadku Ewy to doświadczenie mistyczne - zarysowują pole symboliczne, $\mathrm{w}$ ramach którego sprawa polska, katastrofa historyczna, która dotknęła naród - również życie młodych więźniów - nabiera sensu. Okazuje się, że ma ona wymiar religijny, upadek Polski staje się ważnym momentem dziejów chrześcijaństwa. Można go rozumieć na gruncie ekonomii sensu, którą przynosi wyraźnie kompensacyjna narracja mesjanizmu. Witalistyczny sen Ewy ukazuje symboliczne zaślubiny Polski i Chrystusa (eksponuje to biało-czerwona kolorystyka kwiatów pojawiających się w widzeniu bohaterki) ${ }^{42}$. Widzenie ks. Piotra - odkrywa masochistyczną wartość cierpienia, wpisującego się w perspektywę naśladowania Chrystusa oraz zapowiada misję bohatera, który ma przynieść narodowi wolność.

Sen staje się zjawiskiem, w którym rozgrywają się najważniejsze wydarzenia dramatu - znakomicie to zrozumiał i wykorzystał, parafrazując III część Dziadów w Ślubie, Gombrowicz - związane z jego wymiarem symbolicznym. Uwagę zwraca, zatracona w przywołanych wyżej tekstach XX-wiecznych, dialektyka zagubienia i odnalezienia się, ujawniająca życzeniowy aspekt marzenia sennego, wpisane w nie pragnienie życia wolnego narodu. Sen okazuje się wymiarem, w którym można odnaleźć sens zdarzeń dotyczących traumatycznej sytuacji państwa polskiego, odzyskać pozwalające je interpretować pole symboliczne. Może jednak pozostać przestrzenią błądzenia. Rozgrywa się w dramacie także w sytuacji traumatycznej, w sytuacji uwięzienia; Gustaw/Konrad mówi o doświadczanej ułudzie, lęku i zmęczeniu związanymi ze snem. Mickiewicz rozpisuje pracę wspomnianej dialektyki w losach kilku postaci dramatu. Istotna w związku z tym jest zarówno moralność śniącego - poeta niejednokrotnie akcentuje tę kwestię, kładąc nacisk na rolę wolnej woli człowieka i dokonywanych przez niego wyborów - jak i to, czy zapamięta sen i wyciągnie z niego wnioski dla własnego postępowania. W przypadku Konrada sen zdaje się zaszczepiać ziarno sensu, niezrozumiane przez bohatera - świadczy o tym również

Zob. Z. Kępiński Mickiewicz hermetyczny, PIW, Warszawa 1980, s. 241 i n. W opracowaniach pojawiają się wszakże stwierdzenia negujące fakt, że widzenie Ewy rozgrywa się w trakcie snu (np. M. Cieśla-Korytowska „Dziady”Adama Mickiewicza, WSiP, Warszawa 1995, S. 50). 
jego zachowanie w wieńczącym dramat Ustępie - mające wszakże w nim wzrosnąć w przyszłości.

\section{„Sen, jak cień za ciałem, stąpał za jego duszą!"43}

Krasiński, jak zaświadcza jego korespondencja, w snach przeżywa swój polski los dziedzica pamięci dawnego imperium i mieszkańca podbitego kraju, poddanego cara. Sny te żywią się fantazmatem zarówno martyrologicznym, jak i heroicznym ${ }^{44}$. Widzenie senne stanowi temat wielu utworów poety. Znamienna jest z jednej strony pojawiająca się w nich, zwłaszcza od czasów jego twórczości genewskiej ${ }^{45}$, poetyka wizyjno-oniryczna, związana z fantasmagorycznym obrazowaniem, rezygnującym z mimetycznego przedstawienia rzeczywistości ${ }^{46}$. Z drugiej natomiast - stałość uporczywie powracającego kodu symbolicznego, związanego z wyobraźnią apokaliptyczną i mesjanistyczną (wizją katastrofy Polski i Europy), a także z intertekstualnym odwołaniem do Boskiej Komedii Dantego. Splot apokalipsy i mesjanizmu współtworzy w kreowanych przez poetę snach pracę dialektyki zagubienia i odnalezienia się, która staje się dialektyką straty i odzyskania. Wypada dodać, że nie we wszystkich utworach Krasińskiego aspekt kompensacyjny - odnalezienie się/odzyskanie, jest równie wyraźny.

Taki sen, określony mianem widzenia, pojawia się np. w Herburcie. W onirycznej wizji - przewodnikiem po piekle współczesnej historii, a w zasadzie jej końca, jest Dante, określający je zresztą mianem czyśćca, co daje nadzieję na odkupienie win - bohaterowi zostaje ukazany konający naród; poeta nie identyfikuje go wprost z Polakami, tożsamość ta okazuje się zasugerowana aluzyjnie. Czytamy: „Potem nagle stanęli na szczycie wzgórza i z przeciwka wszedł księżyc, oświecając blado nieprzejrzaną równinę, na niej tysiąc

43 Z. Krasiński Herburt, w: Pisma Zygmunta Krasińskiego [Wydanie Jubileuszowe], oprac. J. Czubek, t. 4, Gebethner i Spółka, Kraków 1912, s. 152.

44 Szerzej piszę o tym w tekście Krasiński postkolonialnie. Wokół doświadczenia słabości poety, w: Romantyzm środkowoeuropejski w kontekście postkolonialnym, t. 2, red. M. Kuziak, B. Nawrocki, Universitas, Kraków 2016. Zob. ponadto M. Piasecka Mistrzowie snu. Mickiewicz - Słowacki Krasiński, s. 153 in. Zob. M. Siwiec Oniryczne apokalipsy w genewskich fragmentach Krasińskiego, w: Wokół Krasińskiego, red. M. Sokalska, Wydawnictwo U), Kraków 2012.

46 Zob. M. Janion Zygmunt Krasiński - debiut i dojrzałość, Wiedza Powszechna, Warszawa 1962, s. $154 \mathrm{in}$. 
krzyżów i tysiąc konających przybitych, jakoby naród jeden cały w godzinie ostatecznej męki" ${ }^{47}$. Godzina ta jest godziną próby - to również powracający u Krasińskiego wątek. Naród staje w sytuacji wyboru: między kuszącym widmem a Chrystusem, ma podjąć swoją ostatnią walkę. Dotąd zło zdawało się tryumfować. Wizja ukazuje także najemników - nie jest przy tym jasne, czy należą oni do prześladowanego narodu - którzy zaprzedali się złu za odpowiednią zapłatę i występują przeciw Bogu oraz ojczyźnie. Krasiński poddaje radykalnej krytyce nowoczesny świat mieszczański. Włada nim prawo ekonomii relizujące się w chciwości - pieniądz, giełda i handel zastępują dawny honor. Figurami tak rozumianej nowoczesności okazują się sprzedajni: poeci, kobiety, kupcy, gracze giełdowi (wyszczególnieni zostają przy tym Żydzi).

To bez wątpienia męczący sen, odznaczający się przy tym różnym stopniem natężenia; zresztą sen zdaje się w utworze także metaforycznym określeniem stanu tryumfu zła, jak zostaje podkreślone - silnego jak nigdy wcześniej ${ }^{48}$. Utwór przenika depresyjny nastrój. Śniący odczuwa smutek, wszechogarniającą ciemność, ma wrażenie zapadania się - siebie i rzeczywistości, chciałby wyrwać się spod władzy wizji. Upadły świat okazuje się zrujnowanym apokaliptycznym cmentarzem:

Zdało się Herburtowi teraz, że niewidziane ze szczytu oręże i zbroje, gruzy i węgle sterczą naokoło. Ujrzał drobne dzieci w kajdanach, umarłe na piersiach matek umarłych; stały pługi samotne, na pół zakopane w brózdach, kościotrupy koni, w siodłach bojowych rozciągnione, leżały, dalej kaplice, rozbite ołtarze i dawnych królów berła i wodzów buławy, walające się w piasku, a im bardziej oddalał się od krzyża, tym bardziej rosło milczenie śmierci ${ }^{49}$

Kwestia odnalezienia się/odzyskania tego, co utracone, i związana z tym nadzieja pozostają ledwo zasugerowane przez Dantego.

Sen ten wraca także w Nie-boskiej komedii części I, we fragmencie Sen, który przynosi apokaliptyczną wizję końca dziejów, umocowaną w myśleniu o przemianach, które zainicjowała Wielka Rewolucja Francuska, zamykając

Z. Krasiński Herburt, s. 144 .

Zob. M. Piasecka Mistrzowie snu. Mickiewicz - Słowacki-Krasiński, s. 219 in. 
epokę ładu teologicznego i inicjując czas demokracji oraz kapitalizmu, jak ukazuje poeta - tryumfu szaleństwa i zła. W takim kontekście pojawia się sprawa narodu, którego dusza znajduje się pod opieką Chrystusa; jego naśladowanie ma stanowić drogę ocalenia. Utwór kończy się przekazem Dantego - podobnie jak było w Herburcie, przewodnika śniącego - zwrócony, jak się zdaje, do narodu polskiego (ponownie nienazwanego wprost), głoszący konieczność religijnej odnowy ludzkości. Odnowa ta ma być warunkiem realizacji epoki trzeciej, czasu Ducha św. Ostateczny kształt przyszłości pozostaje wszakże w świetle utworu czymś otwartym, choć doświadczający sennej wizji bohater powiada: „za późno”, demonstrując w ten sposób swój historiozoficzny pesymizm.

Najpełniej dialektyka zagubienia i odnalezienia się/straty i odzyskania uwidacznia się u Krasińskiego w Trzech myślach pozostatych po ś.p. Henryku Ligenzie - komentowanych zresztą przez Mickiewicza w prelekcjach paryskich jako dzieło profetyczne, przeciwstawiane doktrynie „kościoła urzędowego"50 - zarówno w składającym się na nie Śnie Cezary, jak i w związku z niejako dopełnieniem go przez Legendę.

W pierwszym z wymienionych fragmentów Trzech myśli... powraca znana już z twórczości Krasińskiego poetyka i topika niejasności, zagubienia śniącego, przeżywającego lęk w związku z doświadczaną katastroficzną wizją. Bohater, nawoływany przez głos, wędruje w niewiadomym celu, spotykając tłumy podążające na apokaliptyczny sąd. Uwagę Cezary przykuwa naród (znów aluzyjnie - polski), podejmujący swoją ostatnią, straceńczą, pozbawioną nadziei walkę:

I ujrzałem pośród narodów garstkę ludzi, ubranych w szaty żałobne, garstkę ludzi ujrzałem niosącą sztandar, na którym napisano było: „Naród", ujrzałem ostatnie pokolenie wielkiego plemienia, idące zwolna, jakby za pogrzebem, idące także w nieskończoność - a gdziekolwiek spotkało się z drugimi tłumy, torujące sobie drogę ostatkami szabel Wielu z nich dźwigali szczątki łańcuchów na nogach i dłoniach, byli bardzo bledzi i bardzo znużeni - nieśli dzieciątka konające w ramionach, inni w objęciach trzymali omdlałe niewiasty, podobne do umarłych aniołów. ${ }^{51}$ Reja do Boya, PIW, Warszawa 1977, s. 301 i n. 
Wizja ta przypomina o pojawiających się u Krasińskiego fantazmatach cierpienia syberyjskiego - fantazmat ten powraca w utworze także we wzmiance o „płaczu kopiących w kopalniach"52 - oraz straceńczej heroicznej walki. Naród, o którym mówi sen, jest wrogo, sadystycznie traktowany przez inne narody, które chcą uczynić z niego swojego niewolnika. Ginie osamotniony w boju, natomiast wokół życie toczy się dalej. Tak zostaje zaakcentowany skandal polityki europejskiej, obojętnej wobec losu ginącej Polski.

Scena oniryczna ma wszakże swój ciąg dalszy. Wprowadza on pole symboliczne, pozwalające rozumieć katastrofę narodu i dające nadzieję na przyszłość. Polegli, przemienieni, żyją po śmierci życiem aniołów. Prowadzeni przez Chrystusa schodzą odpoczywać do grobu. Tam mają śnić i nabywać mocy, oczekując na czas odrodzenia ${ }^{53}$.

Sen to również próba śniącego Cezary. Staje się on przy tym strażnikiem jedynej, będącej symbolem ducha narodu, kobiety, która przeżyła jego upadek. Bohater doświadcza przygnębienia i zwątpienia; słyszy głos stwierdzający ostateczne unicestwienie narodu. Jest kuszony wyborem między jakoby naznaczoną śmiercią, stającą się nicością przeszłością, a zwracającym się ku przyszłości życiem. Cezara wybiera przeszłość, która, jak się okazuje, ma zmartwychwstać. Śmierć w zgodzie z logiką mesjanizmu okazuje się przygodną iluzją. Ci, którzy przeszli próbę wierności, zyskują nieśmiertelność. Przekonuje o tym zakończenie utworu, przedstawiające zmartwychwstanie narodu.

Współtworząca Trzy myśli... Legenda - otwiera ją zdanie zaczynające się od „Zdało mi się...", co sugeruje oniryczny charakter widzenia, podobnie pod koniec utworu dowiadujemy się o przebudzenia wizjonera - zawiera narrację wskazującą na historyczne posłannictwo polskiej szlachty związane z realizacją epoki Ducha św. Wiedziona głosem anioła, podąża ona w wieczór wigilijny - po długiej i ciężkiej podróży morskiej - do Bazyliki św. Piotra w Watykanie. To pielgrzymi, ostatni bohaterowie, obrońcy wiary katolickiej. Krasiński nawiązuje w takim ujęciu zarówno do swojej diagnozy upadku świata nowoczesnego, jak i do wyobrażeń związanych z Polską jako przedmurzem chrześcijaństwa. Szlachta polska zostaje przeciwstawiona innym narodom europejskim,

52 Tamże, s. 264.

53 Taki sen odpoczynek, oczekiwanie na wypełnienie się mesjanistycznego sensu dziejów, pojawia się także w Irydionie, w którym chrześcijanie tryumfują nad gnębiącym ich Rzymem (tu "sen grecki" spotyka się ze "snem polskim" - obudzony "senny młodzieniec", Grek, zostaje wysłany na Północ, do "ziemi mogił i krzyżów”). Podobnie rzecz przedstawia się w Przedświcie, w którym sen jest stanem istnienia narodu polskiego, oczekującego na zmartwychwstanie, przechowującego, chroniącego w ten sposób swojego ducha. 
które zapomniały o religijnym powołaniu i wyrzekły się duchowych potrzeb. Polacy, nie lękając się rozpoczynającej apokaliptyczny czas końca historii katastrofy, podtrzymują swoimi szablami kopułę rozpadającej się bazyliki, chroniąc w ten sposób papieża odprawiającego mszę. Giną, ale ich śmierć, w myśl zarysowanej wyżej logiki mesjanistycznej, jest przejściem do życia wiecznego. Utwór kończy się zapowiedzią lepszego losu narodu, dość niejasną, w kontekście realizującej się paruzji - czytamy bowiem: „owszem, im lepiej będzie i synom synów ich"54; być może wszakże paruzja wydarza się na gruncie snu, a profecja dotycząca narodu odnosi się do realnej, ciągle trwającej historii.

Ukazane przez Krasińskiego „sny polskie” proponują pole symboliczne, umocowane w myśli apokaliptycznej i mesjanistycznej, pozwalające rozumieć historię Polski, sytuowaną w kontekście historii europejskiej - zwłaszcza rozpoznania jej głębokiego kryzysu, a także narcystycznej doskonałości wyróżniającej naród polski na tle innych narodów. Moc symboli daje nadzieję na odrodzenie upadłego narodu. Wypada wszakże zauważyć, że zwłaszcza u autora Nie-boskiej komedii - kwestia ta widoczna jest również u Mickiewicza - „sny polskie” okazują się bardziej pesymistyczne, lękowe i depresyjne niż teksty poety, w których, związane z misją polskiej szlachty, narracje kompensacyjne występują bez ramy snu; widać w owych snach także fascynację straceńczym polskim losem i wyobrażeniami klęski. Osobna kwestia to niejasność zagadnienia sprawstwa śniącego (a także niejasność relacji snu do życia na jawie, które prowadzi wybudzony). Zdaje się ono polegać głównie na wierności, na odrzuceniu pokusy zapomnienia o narodzie. Jego zmartwychwstanie z kolei ma wynikać niejako z logiki samej historii, na której realizację często oczekuje się u Krasińskiego we śnie; oczywiście uwzględnione zostają też, najczęściej fantazmatyczne, zasługi.

\section{"Sen jego nawet jest pieśnią i czynem"55}

Słowacki wprowadził w polskim romantyzmie bez wątpienia najbardziej różnorodne spektrum snów ${ }^{56}$. W związku z interesującym mnie tu „snem

54 Z. Krasiński Legenda, w: Pisma Zygmunta Krasińskiego, s. 283.

55 J. Słowacki Samuel Zborowski, w: Dzieła Wszystkie, red. J. Kleiner, t. 13, cz. 1, Ossolineum, Wrocław 1963, s. 144 .

56 Snom w twórczości poety poświęciła książkę M. Siwiec Sen w twórczości Juliusza Słowackiego i Gérarda de Nerval, Universitas, Kraków 1998. Zob. ponadto W. Owczarski Sennik polski. Literatura, wyobraźnia i pamięć (rozdz. Sny srebrne Słowackiego). 
polskim" można przywołać wiele różnych jego wariantów pojawiających się w twórczości autora Samuela Zborowskiego. Trudno nie wspomnieć Kordiana, w którym wizje Strachu i Imaginacji, towarzyszące bohaterowi usiłującemu zabić cara - pojawia się w nich kwestia słabości/mocy, lęków Kordiana, a także symbolika apokaliptyczna, którą poeta wiązał z Polską - uniemożliwiające spełnienie misji, zostają określone mianem snu ${ }^{57}$. Z kolei w Anhellim sen okazuje się melancholijną ucieczką przed aktywnością, pogrąża się w nim zmęczony i smutny bohater odmawiający udziału w zbliżającej się rewolcie; w poemacie sen staje się również metaforą życia nieumocowanego w wartościach, ale też w trakcie snu Szaman demonstruje cud i wywołuje duszę $\mathrm{z}$ ciała Anhellego.

Tu jednak, w związku ze Słowackim, chciałbym zwrócić szczególną uwagę, po pierwsze, na podobny problem, jak ten, który pojawił się zwłaszcza w III części Dziadów, ale można się go dopatrywać także w przywołanych utworach Krasińskiego. Myślę o kwestii zdolności do rozpoznania sensu przekazu sennego i wykorzystania pozyskanej w ten sposób wiedzy. Po drugie natomiast, zajmie mnie specyficzna, wyjątkowa w polskim romantyzmie, koncepcja snu - działania.

Pierwsze z wymienionych zagadnień pojawia się w Śnie srebrnym Salomei ${ }^{58}$. Poeta wprowadza do swojego dramatu sen o zagrożeniu, zapowiadający katastrofę, która dotknie rodzinę Gruszczyńskich za sprawą zbuntowanego ludu ukraińskiego; w dramatach Słowackiego z lat 40. Bóg niejednokrotnie daje Polakom znaki i przestrogi mające kierować ich postępowaniem i wskazywać na splot sprawy Polski ze sprawą ducha. Śniąca Salomea nie rozumie jednak wywołujących w niej lęk snów, które ją nawiedzają, i nie spełnia nakazu śniącej się matki:

[...] śnię ja,

Że matka moja, mi każe,

Abym ja u dobrodzieja

Gruszczyniec, twojego taty,

Prosiła dla niej o konie,

Bo ją człek jakiś brodaty

Ściga, straszy, chwyta w dłonie

I - (rzekła to najwyraźniej,

57 Zob. M. Piasecka Mistrzowie snu. Mickiewicz - Słowacki - Krasiński, s. 97 i n.

58 Zob. tamże, s. 111 in. 
Jakby przestrachem wzdrygnięta - )

Jeśli się Salusia zbłaźni,

A prośby tej nie spamięta,

To będę z dziećmi zarżnięta... ${ }^{59}$

Kolejny symboliczny sen Salomei wskazuje na spełnienie się proroctwa dotyczącego losu matki (potwierdzają to też dalsze wypadki w dramacie). Bohaterka, jak przypuszcza Piasecka, śni ponadto, w trakcie swojego uwięzienia, również zresztą nie rozumiejąc, sen dotyczący Polski, jej męczeństwa, zlokalizowany: „W krainie jakiejś bez brzegu, / Gdzie jedna tylko na śniegu / Plama - okropna - czerwona"60.

Z tym zignorowaniem znaków zapowiadanej katatrofy koresponduje zachowanie Gruszczyńskiego, który nie rozumie znaków i wezwania kierowanego do niego przez Chrystusa. Bohater w końcu z opóźnieniem wyrusza w pole do walki, ale też sceptycznie powiada: „Bar upadł! Bar upadł, Mocanie! / Zaufali Chrystusowi, / A upadli!..." ${ }^{\text {, }}$, nie rozumiejąc rytu mesjanistycznego władającego historią. Z kolei postacią, która rozumie prawdę snu („snu widuna"), jest Wernyhora przepowiadający w hermetyczny sposób dalszy los Polski.

Dialektyka zagubienia i odnalezienia się zostaje niejako zapowiedziana w dramacie Słowackiego, ciągle jednak czeka na realizację, która jest uzależniona od zdolności poznawczych człowieka. Swoista oniryczna pedagogika, którą ukazuje poeta, kończy się krwawo, zapowiadając też upadek Polski. Słowacki zdaje się przekonywać, że trzeba porzucić codzienne nawyki poznawcze (to one utrudniają Salomei rozumienie snu), by rozumieć przekaz oniryczny i wpisać się w boży plan historii' ${ }^{62}$.

Pisząc o śnie - działaniu, mam na myśli nie tylko ważną dla poety perspektywę poznawczą, jaką jest sen anamentyczny, w którym śniący przypomina sobie poprzednie wcielenia i rozpoznaje sens dziejów, nabywając zdolność ich świadomego kształtowania. Chodzi mi przede wszystkim o sen, który

59 J. Słowacki Sen srebrny Salomei, w: Dzieła Wszystkie, , t. 6, Ossolineum, Wrocław 1955, s. 162 i n.

60 Tamże, s. 254. Zob. M. Piasecka Mistrzowie snu. Mickiewicz-Słowacki-Krasiński, s. 115.

61 J. Słowacki Sen srebrny Salomei, s. 153.

62 Jednocześnie jednak trudno odmówić racji Piaseckiej, która zauważa ironiczne skomplikowanie tej kwestii, przekonując, że dana przez Leona interpretacja snu Salomei, podporządkowana właśnie takim nawykom, ostatecznie spełnia się. Bohaterka przecież staje się szczęśliwa ( $M i-$ strzowie snu. Mickiewicz - Słowacki - Krasiński, s. 115 in.). 
Słowacki dość tajemniczo wiąże z działaniem. I tak w Samuelu Zborowskim jest mowa o poecie (aluzyjnie - samym autorze), którego „Sen [...] nawet jest pieśnią i czynem" - twórczością literacką, choć specyficzną, opartą raczej na głosie niż piśmie, a także czymś więcej - sposobem przekształcania świata. Sen okazuje się ponadto w dramacie źródłem odpoczynku i mocy - tak jest w przypadku Atessy, która zasypia, czekając na swoje kolejne wcielenie.

Szczególnie intrygujący jest wszakże fragment utworu, w którym duchy mówią do Eoliona:

Gdy wyrośniesz na człowieka,

Staną ci sny... jak liczny wróg,

I stworzysz świat... jak tworzy Bóg...

Ale nie świat realnych scen,

Lecz nikły świat - jak ze snu - sen.

I złamiesz świat... i pójdziesz wbrew

Wojskami mar... przeciwko ciał,

I będziesz myśl... przemieniał w krew...

Nam dawał moc - i od nas brał,

I będziesz król... lecz będziesz sam...

Albo więc idź... albo się złam... ${ }^{63}$

Fragment ten przedstawia los człowieka, formy obdarzonej świadomością, a także zdolnością śnienia, będącej celem pracy ducha. Okazuje się, że twórczość w świecie genezyjskim ma się rozgrywać niejako w świecie snu - jako walka snów. Dialektyka tworzenia i niszczenia, aktywność o charakterze duchowym, która tworzy świat materii (realizację takiej aktywności Słowacki wielokrotnie ukazuje w Królu-Duchu). Cytowane słowa wskazują na specyficzną podwójną działalność: walkę ducha z materią i zarazem przekształcanie ducha w materię. Tak ma wyglądać umocowana w imperatywie skrajnego heroizmu misja człowieka obdarzonego boską mocą sprawczą. Misja ta okazuje się przy tym naznaczona stygmatem samotności i ryzyka. Cytowany fragment stanowi projekt „snu polskiego”. Zdaniem Słowackiego

63 J. Słowacki Samuel Zborowski, s. 149. M. Piasecka (Mistrzowie snu. Mickiewicz - Słowacki - Krasiński, s. 124 i n.) interpretuje ten fragment dramatu w odmienny sposób - jako próbę i pokusę, za którą stoją złe duchy i która wiedzie do upadku oraz degradacji duchowej, związanej z wyborem wyobraźni kosztem rzeczywistości. Wydaje się wszakże, że u Słowackiego kategorie te nie znajdują się w relacji opozycyjnej, a w dialektycznej. 
droga ducha wiedzie właśnie przez Polskę, przewodzącą w twórczy sposób rozwojowi świata.

\section{w*⿻}

Sen, stanowiąc zdaniem romantyków poszerzenie możliwości poznawczych człowieka, zarazem okazuje się zjawiskiem groźnym, męczącym i wywołującym lęk. Narusza integralność śniącego, kwestionuje władzę jego świadomości, a w przypadku opisywanych tu „snów polskich” przynosi wizje katastro$\mathrm{fy}^{64}$. Jak pisze Geoffrey H. Hartman, posługując się językiem psychoanalizy lacanowskiej, „trauma może wiązać się z rozdarciem porządku Symbolicznego". Jej przepracowanie będzie polegać na odbudowie owego porządku i przywróceniu relacji między nim i podmiotem ${ }^{65}$. Romantyczne „sny polskie” dają zarówno wizję uporczywie powracającego przeżycia traumy historycznej, jak i sposobów jej przepracowania: narracyjne, symboliczne - w przypadku Słowackiego także wskazujące na czyn - wprowadzające zazwyczaj mesjanistyczną ekonomię sensu.

W ten sposób zostaje ukazana polska pozycja depresyjno-kompensacyjna. Powstaje naznaczona resentymentem dialektyka słabości i siły (zagubienia i odnalezienia się/utraty i odzyskania). W ten sposób realne doświadczenie przekształca się w wielką fantazję Polaków - krytykowaną m.in. przez Brzozowskiego $^{\mathbf{6 6}}$ - obejmujących swoimi snami zresztą nie tylko Polskę, ale i całą Europę. Co charakterystyczne, wspomniana dialektyka nie pojawia się w przywołanych przeze mnie, nawiązujących do romantyzmu, tekstach XX-wiecznych - Konwickiego i Gombrowicza, poprzestających na przedstawieniu pozycji depresyjnej ${ }^{67}$.Tak, jakby romantyczna wyobraźnia kompensacyjna już nie działała bądź jakby się chciało, by nie działała.

Wypada wszakże podkreślić, że zagarniająca romantyczne projekty mesjanistyczne rama snu nakazuje myśleć o nich jako o nieoczywistych. Zwróćmy

64 Zob. G. Bachelard Poetyka marzenia, przekład, oprac. i posł. L. Brogowski, słowo/obraz terytoria, Gdańsk 1998, s. 166.

65 Zob. G.H. Hartman Wiedza traumatyczna i badania literackie, s. 390.

66 Do wątku tego wraca pod koniec lat 9o. XX wieku Jacek Kaczmarski w utworze Rechot Słowackiego.

67 Zob. H. Segal Sztuka i pozycja depresyjna, s. 121 i n. Pojęcie to pojawiło się ostatnio w książce Sz. Wróbla Polska pozycja depresyjna. Od Gombrowicza do Mrożka iz powrotem, Universitas, Kraków 2015, poświęconej tekstom autobiograficznym wymienionych w tytule pisarzy. 
uwagę, że wspomniane kompensacyjne odnalezienie się czy odzyskanie nie jest czymś prostym. Stanowi wymagające wysiłku etyczne i poznawcze wezwanie oraz wyzwanie dla śniącego. Jest poprzedzone porażkami, towarzyszy mu niepewność i zwątpienie. Trudno przenieść je w wymiar jawy. W przypadku Mickiewicza i Krasińskiego znamienna jest też różnica między mocną retoryką dyskursu politycznego, w którym pojawia się przekaz mesjanistyczny, dominuje wezwanie, a jego słabym opracowaniem w ramach wyobraźni onirycznej, akcentującym raczej ciężar wyzwania.

\section{Abstract}

\section{Michał Kuziak}

UNIVERSITY OF WARSAW

'The Polish Dream': The Case of the Romantics but Not Only

This article proposes the notion of 'the Polish dream' as it appears in Polish literature at the end of the eighteenth century. The Romantic period saw the development of this unique phenomenon and its symbolic meanings.'The Polish dream'thrives until this day. At its centre lies the traumatic experience of Polish history (or, rather, a variety of such experiences). The dream makes it possible to relive this experience and at the same time to construct a symbolic field through which it can be understood; this symbolic field also defines the horizon of activities. In Romantic literature, this field is associated with messianism. What emerges as a result is the oneiric depressive-compensatory position, which is essential to Polish identity, and which can be found in the works of Mickiewicz, Słowacki and Krasiński.

\section{Keywords}

Romanticism, dream, trauma, (post)dependency, Polish depressive-compensatory position 